\title{
IAMJ
}

INTERNATIONAL

AYURVEDIC

MEDICAL JOURNAL

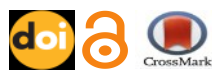

Review Article

ISSN: 23205091

Impact Factor: 6.719

\section{MATRA BASTI THE PANACEA: A NARRATIVE REVIEW}

\author{
Biswajit Dash $^{1}$, Rabindranath Acharya ${ }^{2}$, Gayatri Pattajoshi ${ }^{3}$ \\ ${ }^{1}$ Lecturer, Dept. of Panchakarma, Government Ayurvedic College, Balangir, Odisha, India \\ ${ }^{2}$ Ex-Professor, Dept. of Panchakarma, S.S.N Ayurveda College \& Research Institute, Paikmal, Odisha, India \\ ${ }^{3}$ Medical Officer AYUSH (Ayurvedic), Govt. of Odisha, India
}

Corresponding Author: drbiswajitdash@yahoo.com

\section{https://doi.org/10.46607/iamj09p5012020}

(Published online: November 2020)

Open Access

(C) International Ayurvedic Medical Journal, India 2020

Article Received: 30/09/2020 - Peer Reviewed: 15/10/2020 - Accepted for Publication: 08/10/2020

Check for updates

\begin{abstract}
In Panchakarma, Basti is one of the important therapies. Basti Chikitsa (therapeutic enema) is a natural method to detoxify the body and putting the vivacity into the millions of processes proceeding in the body i.e. it has the power to change the biological rhythm of the body and encourages self-healing. The impurities which are entangled with the body are scraped by the Basti Karma and shown the path of egress to them. It is a holistic treatment with natural things to bring the body back into its natural and homoeostatic state. Basti Chikitsa is considered to be a prime treatment modality among the Panchakarma in Ayurveda. It has not only curative aspects but also preventive and promotive aspects. This Basti treatment also relieves stress from the body and mind to improve the quality of life. Matra Basti is a therapy where least dose of oil/unctuous substance is used. It is preceded by abhyanga (therapeutic oil massage) and Swedana (sudation). Human is the king of the castle (body) so he has to make the decisions how to convert it into more beautiful and healthy state along with its prevention from the rust of impurities.
\end{abstract}

Keywords: Abhyanga, Matra Basti, Swedana, therapeutic enema 


\section{INTRODUCTION}

Panchakarma therapy' is a composite and distinctive system of treatment in Ayurveda. The Basti Chikitsa or Medicated Enema Therapy is one part of the highly effective Panchakarma treatment. One particular form of Basti is Matra Basti. The word 'Basti' or 'Vasti' literally means bladder. In ancient times, bladders of animals were used to perform this procedure. Therefore, the procedure is named as Basti Karma. Basti karma may simply be understood as therapeutic enema. In this process, Medicated decoctions, ghee and oil are administered in the body through anus with the help of instrument specially made for Basti process. The therapy which while moving in the umbilical region, lumbar region, sides of chest and pelvic region churns up the stool including all other morbid matter located there and appropriately eliminates them with ease after nourishing the body can be known as Basti. Truly, Basti means one that holds the urine i.e. urinary bladder.

\section{Action of Basti}

The process of administration of herbal medicines with the help of Basti (urinary bladder) is known as the Basti Chikitsa. Matra Basti is a type of Sneha Bas$t i$ - fat enema. It has been highly praised for its extensive and multi-dimensional use. It doesn't cause any complication and it can be administered at any time to any age of person. The site of action of Basti karma is Pakwashaya i.e. lower gastrointestinal tract, which is the main site of Vata Dosha. Hence, Basti is useful for the treatment of vitiated Vata ${ }^{1}$. Vata is the bio-energy responsible for all voluntary \& involuntary activities of the body. In normal or physiological states Vata Dosha is responsible for all important functions of the body like heart beats, inspiration and expiration, peristaltic movements, musculo-skeletal movements, urination, defaecation, menstrual discharge, semen ejaculation and even delivery process. So, basti is helpful in preventive $\&$ curative aspect. For all these conditions especially in case of constipation, lower backache, gout, rheumatism, sciatica, arthritis, nervous disorders, headache, emaciation, muscular atrophy, etc.

Broadly Basti is of two types -

Table 1: Showing type of Basti

\begin{tabular}{|l|l|l|l|}
\hline Sl.no. & Name of Basti & Material Used & Quantity \\
\hline 1. & Niruha Basti & Kashaya Dravyas (Decoctions) & Up to $1200 \mathrm{ml}$ \\
\hline 2. & Anuvasana Basti & Sneha Dravyas (Oils) & Up to $300 \mathrm{ml}$ \\
\hline
\end{tabular}

Incorrect diet pattern and modernised lifestyle is responsible for many diseases, as the Vata Dosha gets vitiated. In this pathological condition the Basti karma helps to reset and maintain the balanced state of Vata Dosha and it also helps in treatment of such diseases. Thus, Basti karma is the most important and powerful treatment procedure among all the five procedures in Panchakarma. Basti is said as half of the treatment of Ayurveda $^{2}$. Unlike Vamana and Virechana, Basti is not only cleansing process. It performs various types of functions according to the type of Basti implement- ed e.g. Shodhana Basti acts as a cleansing process; Brimhana Basti is nutritive in function. It is the best treatment for Vata Dosha, as Vata is the cardinal factor because pitta and Kapha are immobile in nature. It is only the vitiated Vata Dosha that carries the pitta and Kapha Doshas along with it to cause the diseases. If the Vata Humor alone is under control, then the chances of gaining ill-health is much reduced. This is why Basti is considered as the most proactive therapy of Panchakarma and in Ayurveda it is regarded as the treatment above all or the total treatment. 


\section{Indications and Contraindications of Matra Basti:}

Table 2: Showing Indications and Contraindications for Matra Basti

\begin{tabular}{|c|c|c|}
\hline Sl. No. & Indications $^{3}$ & Contraindications \\
\hline 1. & Vyayama karshita - those who have got weak due to excessive exercises & Ajeerna and Day Sleep ${ }^{4}$ \\
\hline 2. & $\begin{array}{l}\text { Karma karshita - people who are debilitated due to excessive work, } \\
\text { strenuous work }\end{array}$ & $\begin{array}{l}\text { All types of diarrhoeas, dysenteries, } \\
\text { per rectal bleeding }\end{array}$ \\
\hline 3. & $\begin{array}{l}\text { Bhara karshita - people who are debilitated due to excessive lifting of } \\
\text { weights }\end{array}$ & Diabetes \\
\hline 4. & Adhwa karshita - people who are debilitated due to excessive walking & Severe anaemia \\
\hline 5. & Yana karshita - people who are debilitated due to excessive travelling & $\begin{array}{l}\text { Breathlessness, Pulmonary tubercu- } \\
\text { losis }\end{array}$ \\
\hline 6. & $\begin{array}{l}\text { Stree karshita - people who are debilitated due to excessive indulgence } \\
\text { in sexual intercourse }\end{array}$ & Hypoproteinemia \\
\hline 7. & Durbala-excessive weakness & Infantile problems \\
\hline 8. & $\begin{array}{l}\text { Vatabhagneshu - people who are suffering from diseases caused due to } \\
\text { Vata vitiation }\end{array}$ & Senile debility, etc \\
\hline
\end{tabular}

\section{Matra Basti Instruments}

Syringe of 100cc, Disposable Gloves, Simple rubber catheter of number 10 or 12 .

Method of administration of Matra Basti, Before the administration of Matra Basti, the Patient is asked for a light meal which is neither too oily nor too dry and not more than $3 / 4^{\text {th }}$ of the usual quantity. The patient is done abhyanga with the medicated oil over the abdomen and low back region. After this, hot water fomentation / Bashpa Swedana is done. After the completion of this pre requisites, the patient is advised to take left lateral position with left lower extremity straight and right lower extremity flexed on knee and hip joint the patient is asked to keep the left hand below his/her head. A little amount of oil is applied to the anus, then $75 \mathrm{ml}$ of lukewarm medicated Oil is taken in enema syringe. Rubber catheter is oleated with oil and is attached to the enema syringe. Then after removing the air from enema syringe, rubber catheter is inserted into the anus of the patient upto 4-5 inches. The patient is asked to take deep breath while introducing the catheter and medicated oil. Complete oil is not admin- istered, in order to avoid entrance of Vayu into the Pakvashaya which may produce discomfort. After the administration of Basti, the patient is advised to lie in supine position and patient's buttocks is gently tapped and legs are raised few times so as to raise the waist. After a while patient is advised to get up from the Droni and take rest. But if adverse effects like bulging of abdomen, gas in abdomen, pain or discomfort in abdomen appear then the following measures are used:

a. Pessary

b. Purgation with castor oil is given.

c. Fomentation

d. Use of Tikshna Basti- Cow urine or Gomutrasava is used.

\section{Do's and Don'ts:}

The Matrabasti does not demand any regimen of diet or behaviour. It can be given at all times and in all seasons without any restriction. Whereas, Acharya Vriddha Vagbhata has restricted the day sleep after being treated with Matrabasti. ${ }^{5}$ 


\section{Some commonly used Sneha Yogas in Matra Basti ${ }^{6}$ :}

Table 3: Showing Some commonly used Sneha Yogas in Matra Basti

\begin{tabular}{|l|l|l|}
\hline Sl No. & Condition & Name of Sneha Yogas \\
\hline 1. & Vataja & $\begin{array}{l}\text { Mahanarayana Taila, Bala Taila, Shuddhabala Taila, Ksheerabala Taila, Dhanwanta- } \\
\text { ram Taila, Dashamoola Taila, Swadamstradi Taila, Ketakyadi Taila, Sahacharadi Taila, } \\
\text { Balashwagandhadi Taila And Indukantam Ghrita Etc. }\end{array}$ \\
\hline 2. & Pittaja & Murchita Goghrita, Chatuhsneham, Madhuyashtyadi Taila, Sukumara Ghrita Etc \\
\hline 3. & Kaphaja & Triphaladi Taila, Saindhavadi Taila, Pippalyadi Taila, Etc \\
\hline 4. & Raktaja & Chandanabaladi Taila, Changeri Ghrita, Etc \\
\hline
\end{tabular}

\section{DISCUSSION}

The Classical term Matrabasti is popular because of its dose only, as the Sneha is administered in the least quantity. It can be used effectively in many conditions while all Acharyas explained about Matra Basti, as most safe and easy wherein the other varieties of Basti are contraindicated. Since, it is one of the simplest forms of Basti and involves no complications it can be administered without many hassles or prolonged preparations.

\section{a.) Role of the Sneha (Lipids) Dravyas used in Matra Basti:}

The Sneha Dravyas includes Ghrita, Taila (oil), Vasa and Majja (bone marrow) and each one is having its specific properties, and accordingly it yields its beneficial effects. Sneha in general is Vatahara, Mridukara (produces softness in the channels and tissues, in turn helps for easy elimination of waste substances) and removes the obstruction the channels produced by the Mala i.e. Malanam Vinihanti Sangam. ${ }^{7}$ As per the Snigdha Guna, it produces unctuousness in the body in turn it helps for easy elimination and by Sukshma Guna it helps the drug (by its potency) to reach into the Srotas (micro channels). Apart from these functions, it protects the mucous membrane from the untoward effect of irritating drugs in the Basti Dravya. In colon, production of short- chain fatty acids (SCFA) is produce by abundant bacterial fauna. Colonocytes can take SCFA up efficiently and in part utilize them as nutritional sources. Both squamous stratified mucosa of lumen and columnar simple epithelium of intestine absorb readily SCFA. Passive diffusion of the unionized form across the cell membrane is currently admitted. In the lumen, the necessary pro- tonation of SCFA anions could come first from the hydration of $\mathrm{CO}_{2}{ }^{8}$ SCFAs might play a key role in the treatment of the metabolic syndrome, bowel disorders, and certain types of cancer. In clinical studies SCFA administration positively influenced the treatment of ulcerative colitis, Crohn's disease and antibiotic - associated diarrhoea. ${ }^{9}$

\section{b.) Probable mode of action of Matra Basti:}

The human colon has a nominal mucosal surface area of about $2000 \mathrm{~cm}^{2}$ but in reality, the total absorptive area is even greater because colonic crypt cells are capable of absorption as well as secretion ${ }^{10}$. Drug absorption is determined by the drug's physicochemical properties, formulation, and route of administration. In rectum, drugs may cross cell membranes by passive diffusion, facilitated passive diffusion, active transport or pinocytosis. Sometimes various globular proteins embedded in the matrix function as receptors and help transport molecules across the membrane. ${ }^{11}$ Basti is the best treatment for Vata as said by Acharya Charaka "Bastihi Vataharanam". Basti drug first reaches to the Pakvashaya (large intestine). Pakvashaya is the chief site of Vatadosha. Thus, by its action on the chief site, Bastigets control on Vata all over the body. Pakvashaya is the site of Purishadharakala. Commentator Dalhana has

said Purishadhara and Asthidhara kala are one and same. ${ }^{12}$ Basti drugs directly acts on different $k a$ la also. Acharya Sushruta has mentioned that $6^{\text {th }}$ Basti nourishes MamsaDhatu,

$7^{\text {th }}$ Basti nourishes MedaDhatu,

$8^{\text {th }}$ Basti nourishes Asthi Dhatu and $9^{\text {th }}$ Basti nourishes Majja Dhatu' ${ }^{13}$. 
So, it has Vatasamshamana and Rasayana properties. Hence, it is very good in Vatavyadhis. Thus, through Basti, one can achieve Shamana of the Vayu dosha as well as Snehana of Dhatus. According to contemporary medical science, as per Enema concerned, in trans-rectal route, the rectum has a rich blood and lymph supply and drug can cross the rectal mucosa like other lipid membrane. So, by entering in general circulation, the Basti drugs acts on whole the body. Basti may act through the nervous system or through the enteric receptors. It may increase the secretion of local enzyme or neurotransmitters. Basti influences the normal bacterial flora, thus it increases the endogenous synthesis of vitamin $\mathrm{B}_{12}$, vitamin $\mathrm{K}$ etc. Before the matra basti, abhyanga (oil massage) - directly acts on muscles and makes them strong. The root of Mamsavaha Srotas is Snayu (ligaments), Tvacha (skin) and Raktavahini (blood vessels). Hence, Abhyanga is done over Tvacha and Snayu and also it involves Raktavahini. So here, direct benefit is achieved at Mamsavaha Srotas. Abhyanga nourishes deeper Dhatus too. While Swedana (fomentation) is Srotoshuddhikara (clears up the micro channels), Agni Deepaka, Kaphavata Nirodhana (antagonist of Kapha). It decreases all Sthambha (stiffness) and the heat administration by Swedana may produce hypno analgesic effect by diverted stimuli.

\section{c.) Retention of Matrabasti:}

The normal Pratyagamana Kala of Sneha Basti is 3 Yama i.e. 9 hours $^{14}$. Being a type of Sneha Basti, the Pratyagamana Kala of Matrabasti is also 3 Yama. There is no harm if Matrabasti retains in the body because, while describing Anuvasana Basti it has been said that it is not harmful to body even in the event of its being retained in the body for a whole day. Also, the dose of Sneha in Matrabasti is very small, which can get easily absorbed in the body without coming out. If basti material returns much earlier, it cannot produce the desired effect in the body.

\section{d.) Importance of left lateral position ${ }^{15}$ :}

By maintaining the left lateral procedure, during the administration of Basti, the Bastidravya reaches the Pakwashaya which resides in the left side. Charaka opines by attaining this posture, Gudavalis will be relaxed. He also mentions that the Grahani is situated in the left side. Gangadhara says; Agni, Grahani and Nabhi are present in the left side. Jejjata comments Agni is present in left side over the Nabhi, Guda has got a left sided relation with Sthoolantra. So, the Bastidravya can reach to the large intestine and Grahani, as they are present in the same level.

\section{CONCLUSION}

Vata is the 'kinetic' principle that is associated with motion and movement of body. Among the Panchamahabhutas, Vata Dosha is represented as vayu. Dhatus are managed by regulating the Dosha associated with them. Basti Karma is a part of the highly effective Panchakarma treatment modality. While one particular form of Basti is Matra Basti. It acts in the body in four dimensions i.e. by its action of unique Procedure, Drug, Sroto Shodhana and regulation of Gut Brain ${ }^{16}$ system. According to pharmaco kinetics, drug given in rectal route will have faster absorption and higher bio availability. This Ayurvedic therapeutic enema is just like a diamond in the hand once you give 100 percent trust towards Basti, with integrity it will definitely bring revolution in the ill health. It develops an amity in the body by blowing out all the dross hence it keeps the person in healthy state. It gives a new life just like caterpillar's life cycle. Caterpillars experiences the gloom, when they are wrapped within the cocoon. whenever the coon burst, they wash away the prune rust. now caterpillar becomes a butterfly, to fly high up in the sky. In the same way, the intestines experiences uneasiness when they are covered with impurities, as soon as the vitiated Doshas are flushed out by Basti Chikitsa, intestines get detoxified and feel refresh, light with rejuvenation. It is a powerful technique which helps to earn infinite potential of healing. This 'Matra Basti' therapy is a panacea for Paediatric to Geriatrics. This can be easily practised starting from Neurological problems to Sports Medicine. Basti Therapy is gleam of light that draws away the darkness of deleterious grime. This study suggests that Matra Basti can be an easy mode of treatment. We recommend that good clinical stud- 
ies to be done on different disorders in both Preventative and Curative aspect. This therapy needs more research and standardization.

\section{REFERENCES}

1. Vagbhhata, Ashtanga Hridayam; Dr. Bramhanand Tripathi, Reprint 2009; Chaukhamba Sanskrit Pratishthan, Varanasi; Pg.229 (As. Hri. Sut. 19/1)

2. Agnivesha, Charaka Samhita; Dr. Bramhanand Tripathi, Vol-II, Reprint 2009; Chaukhamba Surbharati Prakashan, Varanasi; Pg. 1169. (Ch. Si. 1/39)

3. Agnivesha, Charaka Samhita; Dr. Bramhanand Tripathi, Vol-II, Reprint 2009; Chaukhamba Surbharati Prakashan, Varanasi; Pg.1223 (Ch Si 4 / 52)

4. Vridha Vagbhata, Astanga Samgraham; Kaviraj Atri dev Gupt, Vol-I, Edition 1993; Krishna Das Academy, Varanasi; Pp. 408, Pg. 206. (As. Sam Sut 28/9)

5. Prof. Ravidatta Tripathy, Astanga Samgraha, sutrasthanam, published by Chaukhambha Sanskrit Pratisthan, Delhi, 2018 ed, P.No. 503, (A.S. Su. 28/8)

6. Mahadevan L, Critical Analysis of Ayurvedic Formulations, $1^{\text {st }}$ edition, 2014 SMIAEC Trust, Pg. 228-386.

7. Agnivesha, Charak Samhita, Siddhisthan1/7, Vol -2, editor Brahmanand Tripathi, Chaukhamba Surbharati Prakashan, Varanasi 2007. pp. 26-28.

8. Bugaut, Maurice. "Occurrence, absorption and metabolism of short chain fatty acids in the digestive tract of mammals." Comparative Biochemistry and Physiology Part B: Comparative Biochemistry 86.3 (1987): 439 472.

9. Binder H. J. 2010. Role of colonic short - chain fatty acid transport in diarrhoea. Annu. Rev. Physiol.72: 297-313

10. Drug Absorption available from http://www.msdmanuals.com/professional/clinicalpharmacology/pharmacokinetics/drug-absorption (cited on 11 Sept 2015)

11. Singh SK, Binder HJ, Boron WF, et al. (1995) Fluid absorption in isolated perfused colonic crypts. J Clin Invest 96:2373-2379.

12. Kasutre H. S, 6th edition. Baidynath Ayurveda Bhawan; Ayurvediya Panchakarma Vijnana. Pg 471.

13. Ibidem, Sushruta Samhita (2), Anuvasanauttarbasti chikitsa Adhyaya. 37:1-76. 164

14. Vagbhata, Astanga Hridayam; Dr. Bramhanand Tripathi, Reprint 2009; Chaukhamba Sanskrit Pratishthan, Varanasi; Pg.234 (As. Hr. Sut 19/30)
15. Dr. Brahmanand Tripathi, Charak Samhita Vol-II, published by Chaukhambha Surbharti Prakashana, Varanasi, 2012 edition, P. No. 1197, (Ch. Si. 3/24)

16. Wood, J.D: Physiology of enteric nervous system, In Johnson L.R, ed Physiology of gastrointestinal system, Vol.1, New York raves Press, 1981, pp-1-37

\section{Source of Support: Nil \\ Conflict of Interest: None Declared}

How to cite this URL: Biswajit Dash et al: Matra Basti The Panacea: A Narrative Review. International Ayurvedic Medical Journal \{online\} 2020 \{cited November, 2020\} Available from: http://www.iamj.in/posts/images/upload/2606 2611.pdf 